\title{
$\checkmark$

\section{Conservation of the estuarine zone of the Goiana and Megaó rivers in northeastern Brazil: an analysis of the strategies adopted by fisherwomen communities *}

\section{Conservação da zona estuarina dos rios Goiana e Megaó, no nordeste brasileiro: uma análise das estratégias adotadas pelas comunidades de pescadoras}

\author{
Amanda Braga de Melo Fadigas ${ }^{\circledR, 1}$, Loreley Gomes Garcia ${ }^{2}$
}

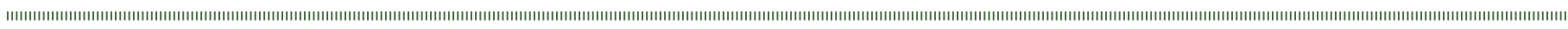

\section{ABSTRACT}

This study analyzed the strategies adopted by a community of fisherwomen to protect their territory in an estuarine zone, on the Brazilian northeastern coast. The survey found that the women directed their efforts towards a sustainable management of fisheries resources and an effective political action to obtain the creation of the Extractive Reserve Acaú-Goiana. The analysis showed that local communities, like these fisherwomen are fundamental to coastal conservation, given their knowledge about the environment and their participation in management processes.

Keywords: shellfish collectors, artisanal fishing, environmental degradation, participation, extractive reserve

\section{RESUMO}

Este estudo analisou as estratégias adotadas por uma comunidade de pescadoras para proteger seu território em uma zona estuarina, na costa do nordeste brasileiro. A pesquisa constatou que as mulheres direcionaram seus esforços para uma gestão sustentável dos recursos pesqueiros e uma ação política efetiva, obtendo a criação da Reserva Extrativista Acaú-Goiana. A análise mostrou que comunidades locais, a exemplo das pescadoras, são fundamentais para a conservaçấo costeira, dado o seu conhecimento sobre o meio ambiente e sua participação nos processos de gestão.

Palavras-chave: marisqueiras, pesca artesanal, degradação ambiental, participação, reserva extrativista.

\footnotetext{
@ - Corresponding author: amanda01dir@gmail.com

1 - Institute of the Environment, Universitat de Girona, Girona, Catalonia, Spain.

2 - Postgraduate Program in Sociology, Universidade Federal da Paraíba, João Pessoa, Paraíba, Brazil.
} 


\section{INTRODUCTION}

Coastal populations that live from artisanal fishing are affected by the conflict between economic growth and environmental conservation. Some factors, such as agricultural and industrial activities, increased coastal degradation, and forced the fishers populations to adopt strategies that ensure both their livelihood and environment conservation (Hanazaki, 2007; Lopes et al., 2011). The most common strategy has been to maintain traditional fishing practices (Berkes et. al., 2000; Cardoso, 2003; Griffin, 2009; Rebouças et. al., 2006; Silvano \& Valbo-Jorgensen, 2008) while also engaging in the creation and management of protected areas (Campbell \& Vainio-Mattila, 2003; Fadigas \& Garcia, 2010; Heyman \& Granados-Dieseldorff, 2012; Santilli, 2005; Soma \& Vatn, 2009; Thomson \& Gray 2009).

The Brazilian National System of Conservation Units (Brasil, 2000) provides a particular category of protected area called "Extractive Reserve" (Resex), where traditional populations survive through sustainable extractive activities. The main goals in these cases are to protect the livelihoods and cultures of these populations, and to ensure a selfsustainable exploitation of the natural resource. The Resex is characterized by intensive participation and co-management between government environmental agencies and the local population (Di Ciommo \& Schiavetti, 2012; Fadigas \& Garcia, 2010; Santilli, 2005).

The Resex experience, which began in the Amazon with rubber tappers and rural workers (Santilli, 2005), has expanded to other Brazilian biomes and traditional populations. This was the case for the "Marine Extractive Reserve", which involves exclusively small-scale fishers ( $\mathrm{Di}$ Ciommo \& Schiavetti, 2012; Santilli, 2005). One of the traditional populations engaged in coastal zone protection are the women shellfish collectors. They have emerged from invisibility through their work, maintaining artisanal fishing techniques, and monitoring the quality of their environment and, finally, through their inclusion in the decision-making process (Agarwal, 2007; Aguilar \& Castañeda, 2000; Di Ciommo \& Schiavetti, 2012; Fadigas \& Garcia, 2008; Simonian, 2006; Zhao et al., 2012).

There are still knowledge gaps with regard to the role and mechanisms used by the fisherwomen as protagonists in coastal protection. The aim of this paper is to analyze the strategies and contributions employed by fisherwomen at the Goiana-Megaó estuary, in northeastern Brazil, to protect and defend their fishing territories and rights. The study area is the Paraíba (PB)/Pernambuco (PE) state border, which have undergone a long period of environmental pressure. For this, was identified the universe of the shellfish collectors and their actions that resulted in the estuary official protection.

\section{MATERIAL AND METHODS}

Fieldwork (March 2007 and May 2008) was conducted during visits to the Extractive Reserve Acaú-Goiana in the selected communities of Acaú and Carne de Vaca, in northeastern Brazil. Acaú is on the southern coast of Paraíba state; Carne de Vaca is on the northern coast of Pernambuco (Figure 1). Both communities are under direct influence of the Goiana and Megaó estuary and have a high concentration of fisherwomen.

According to the census (IBGE, 2006), in both communities the main activities responsible for income are the sugarcane agribusiness, industry, public administration, and small trade. Fishing, despite having a strong tradition and occupying a large part of the adult population, is not cited in any official record as a source of local income. Fishing in the estuary exceeds sea fishing in number of people and fishing amount, ensuring the livelihood of the local households. The estuary (approximately 4,800 ha), is located in the Goiana river basin, and inserted into the Atlantic Rain Forest biome, with the presence of a mangrove ecosystem (CPRH, 2003).

\subsection{Interview with the key informants}

In March 2008, three fisherwomen were selected in the communities as key informants, for their leadership and community representation (Denzin \& Lincoln, 2003). Considering their expert knowledge of their communities (Rossman \& Rallis, 2003), they were interviewed with open questions recorded in digital audio, and posteriorly was analyzed through discourse analysis (Levin, 1987) with the goals of reconstructing the Resex history and to identify local protagonists.

\subsection{Interview with the women shellfish collectors}

This step occurred in March and April 2008. Considering an estimated universe of 300 , a sample of 30 fisherwomen was delimited by purposive sampling with a sufficient sample size until the saturation point, where additional interviewing contributed no new information. To maintain the speech heterogeneity, age variations were considered as well as time spent having worked as fisherwomen. The interview consisted of open, semi-open, and closed questions whose objectives were to characterize the shellfishing context, resource management, community organization, and creation of the Extractive Reserve (Aguilar et al., 1999). Descriptive statistics were used to analyze the data (Spink, 1995).

\subsection{Analysis of the administrative process of Resex creation}

The administrative process of the Extractive Reserve (Resex) Acaú-Goiana was filed in January 2002 by the Brazilian Institute of the Environment and Renewable Natural Resources (IBAMA) under \# 02001.000442/2002-41. The research analyzed the Resex creation history, identifying key interest groups and community leaders. Descriptive and discourse analyses were used (Spink, 1995) observing all documentation, including the community petition, official statements, technical reports, and audio files, and the Public Consultations were monitored as well.

\section{RESULTS AND DISCUSSION}

\subsection{The fisherwomen and their link to the environment}

Though realizing the profession of fisherwomen (shellfisher women, filleters, shellfish pickers, crabmeat removers, fish skinners, or aquaculture workers), these women are invisible within a culture where men tend to perform the functions 

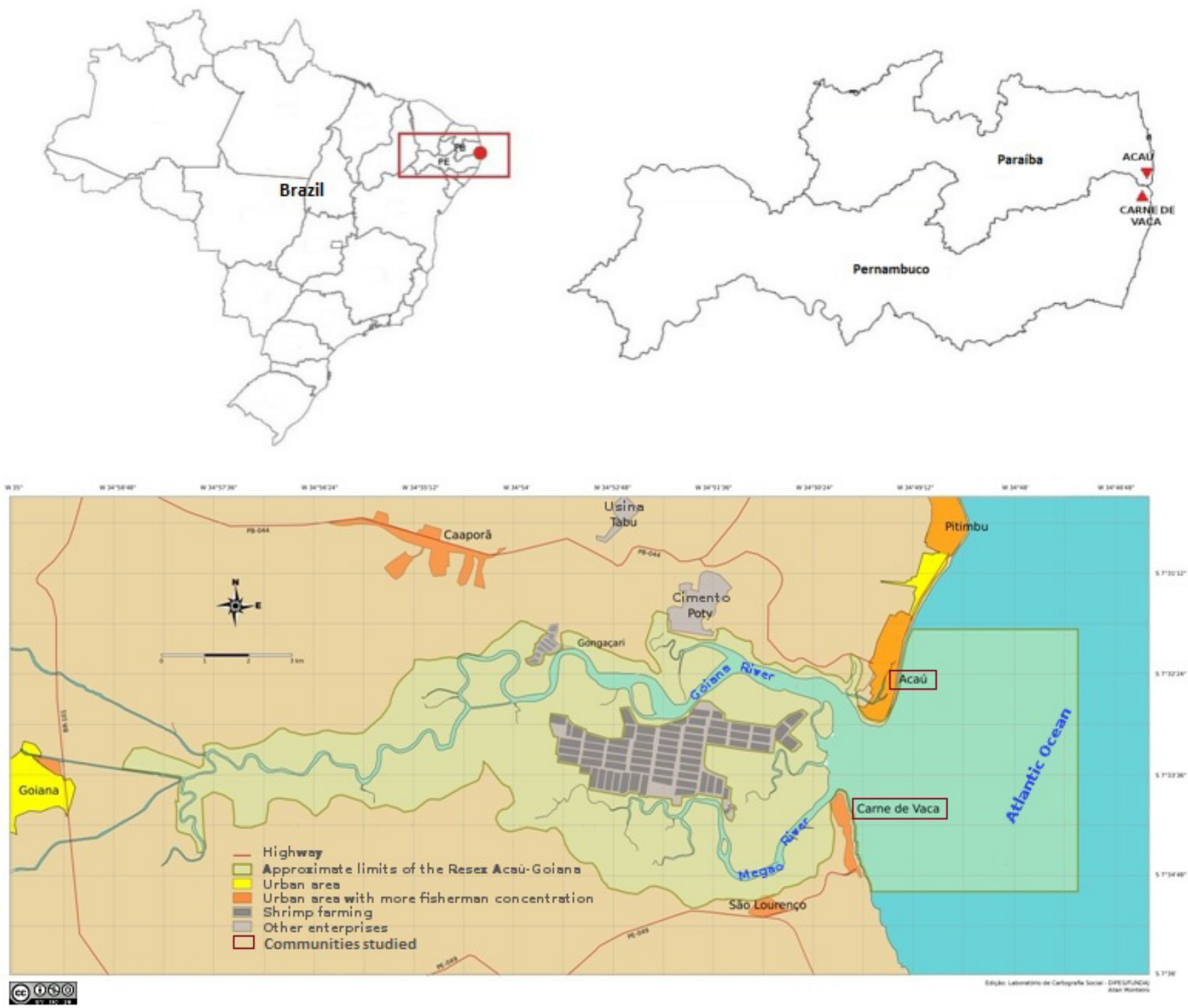

Figure 1. Study Area, showing the location of the Extractive Reserve Acaú-Goiana especially for communities Acaú and Carne de Vaca.

Sources: Ministry of Environment, Brazilian Institute of the Environment and Renewable Natural Resources, Environmental Development Board/ Project "Extractive Reserves and artisanal fishing: ethnography of socioenvironmental field in Pernambuco" (Fundaj/Facepe), produced by Allan Monteiro.

Figura 1. Área de Estudo, mostrando a localização da Reserva Extrativista Acaú-Goiana com destaque para as comunidades Acaú e Carne de Vaca.

Fontes: Ministério do Meio AmbientelInstituto Brasileiro do Meio Ambiente e dos Recursos Naturais Renováveis/Diretoria de Desenvolvimento Socioambiental. Projeto "Reservas Extrativistas e pesca artesanal: etnografia do campo socioambiental em Pernambuco" (Fundaj/Facepe), produzido por Allan Monteiro.

considered more important to society (Aguilar \& Castañeda, 2000; Dias et al., 2007; Machado, 2007; Oliveira, 1993; Simonian, 2006; Zhao et al., 2012).

Within the fishing culture, collecting shellish became a feminized activity essentially for two reasons; first, because of the cultural construction that offshore fishing is dangerous (and therefore for men), and that other fishing categories are "lesser" fishing (Machado, 2007), and therefore easily carried out by women (Hapke, 2001). The second, a consequence of the first, is that historically, in the absence of men (during the high seas fishing season), sustaining the household fell to the women, who saw shellfishing as an important livelihood (Dias et al., 2007).

Many of these fisherwomen are originally from the region surrounding affected by the estuary of the rivers Goiana and Megaó, which serves to strengthen social links in the area. At about 16 years of age, girls already experience shellfish gathering as a profession. However, a high concentration of fisherwomen had their first shellfishing experience while in the 6 to 10 years age range. Further, there are two well- 
defined profiles of fisherwomen: one that works on the shellfish banks, and one that works on land.

The fisherwomen of the shellfish banks composed, at the time of our study, a group of approximately 300 shellfish collectors that reside mostly in Acaú and Carne de Vaca. This region is experiencing an increase in the number of women working in artisanal fishing who are also potential agents for modification of the environment. What highlights the role of the fisherwomen in this environment is that their mode of fishing is indispensably linked to the estuary. It roots these women to this territory, making them the main interested in exercising leading roles for management and conservation of the area.

The representative politics of the land-based fisherwomen complement the actions taken by the shellfish bank fisherwomen. The land-based fisherwomen with their origins in the fishing environment have learned the bases of shellfish collecting; yet, they have sharpened their gaze, and realized that from the land, thru leadership, they can better represent both the history and interests of their group in the public sphere. Also, they play an important role outside the communities, through partnerships with other fishers collectives, thus consolidating a network of interests and collective knowledge about traditional fishing.

\subsection{Strategies for fishing management and estuary conservation}

Shellfishing is a category of fishing normally exercised by women, who collect shellfish and/or crustaceans (Fadigas \& Garcia, 2010; Dias et al., 2007; Di Ciommo \& Schiavetti, 2012). Shellfish (though primarily collected for the external market) are also an important item in the diet of local families $(87 \%$ of the respondents in Acaú, and $80 \%$ Carne de Vaca).

The fisherwomen usually use the estuarine zone, mainly on the shellfish banks, and in some cases in the mangrove forests. There are no maps of the shellfish banks, or studies verifying the carrying capacity of the estuary. However, the interviewed fisherwomen indicated knowledge of their geographical locations, and classified them by productive seasons. Fisherwomen maintain collective management of the shellfishing, including which banks must enter into rest for reproduction, and growth of the shellfish.

Being traditional, shellfishing requires little equipment and has low environmental impact; this then characterizes the fisherwomen as a traditional population. It was observed that some are constantly adapting their tools to work in the capture process (Berkes et. al., 2000; Cardoso, 2003; Rebouças et. al., 2006; Silvano \& Valbo-Jorgensen, 2008), for instance, the handmade $p u c ̧ a^{11}$

All the interviewees agreed when describing the general harvesting process. During low tide, the fisherwomen dig into the mud with their hands, until they notice the presence of shellfish, and then proceed with the removal, while selecting

1 - Puçá consists of a wooden stick, on one end of which is attached a wire basket, the screen size performs the sifting and therefore selection of the shellfish, allowing the capture of only adult shellfish. by size. When the water level is high, the fisherwomen dig the mud with the puçá, removing only the shellfish that pass through the mesh.

The research (during collection) detected a particular characteristic that reinforces the importance of these fisherwomen to the estuary management. According to some respondents, shellfish grow to reach an ideal size, when the mud on the banks is turned or "handled". The interviewees were unable to explain the reason for this phenomenon; they only know this empirically. In fact, by digging in the mud, the fisherwomen allow the shellfish, (which feed by filtering the water) to absorb "fresh" organic matter, thus aiding the species to reach an appropriate size for collection (Barreira \& Araújo, 2005).

This group guards a vast historical knowledge concerning the estuary of the rivers Goiana and Megaó. This knowledge includes biotic, abiotic and social aspects and a mindfulness of the variations generated by both natural and anthropogenic factors.

The technical studies made by the public environmental agencies (CPRH, 2003; IBAMA, 2002) corroborate the local knowledge of the fisherwomen, identifying the main factors causing estuarine degradation during the last decades and a collapse in 1999, that directly affected the shellfish harvest and those who depended upon it.

Up until the 1990s, it was still possible to find the estuary in good condition (IBAMA, 2002), however some elements of the fishing fauna, as indicated by the fisherwomen, have become quite scarce in the estuary. In the case of finfish species, $93 \%$ of respondents in Carne de Vaca, and 100\% in Acaú noted scarcity. For natural non-farmed shrimp, all interviewees in Carne de Vaca, and 93\% in Acaú, noted a sharp drop. A full $80 \%$ of respondents in Carne de Vaca, and $93 \%$ in Acaú pointed out the shortage of crab. The only resource that has maintained a balance between abundance and scarcity are the shellfish, despite having been reduced. This last observation was indicated by $40 \%$ of the respondents in Acaú, and $73 \%$ of the respondents in Carne de Vaca.

This deterioration of the environment assumes different aspects. Technical studies (CPRH, 2003; IBAMA, 2002; IBGE, 2006) of the Goiana river basin reveal that certain economic activities in the area are probably the main cause. This research notes that the perception of the communities fisherwomen about this environmental degradation coincides with the technical analysis that points to agricultural, industrial, and shrimp farming activities as the main sources of damage to the estuarine zone, and the consequent fish shortages in the region.

These activities breached environmental regulations through the emission of effluents without proper treatment, and by the use of pesticides, contaminating the rivers, through prohibition of access to the river by the fishing community, and removal of remnants of the Atlantic Rain Forest and mangrove forest.

The ability of fisherwomen to detect the problems and their consequences for the fishing environment allowed for a social mobilization (Fadigas \& Garcia, 2010; Heyman \& Granados-Dieseldorff, 2012; Santilli, 2005; Soma \& Vatn, 2009). They demanded that public environmental agencies provide official protection for the area. Were crucial in 
this process that previously fisherwomen were involved in different associations. Adding to this was the work done by the fisherwomen leadership forwarding proposals amidst distinct stakeholders.

The first proposal for environmental protection related to fisheries issues came from Acaú in 1999, and tried to establish a period of prohibition for shellfish collection. This focused on population recovery, an already well established method used to manage others species such as shrimp and lobster. However, this would be an isolated effort, focused on the recovery of a single species, whereas the whole ecosystem was at risk.

After several discussions, the fisherwomen proposal aimed estuary protection in a direct and continuous way. Through a collective demand to the government, (represented by IBAMA), the creation of a protected area that allow comanagement was requested. The most appropriate existing model was the Marine Extractive Reserve, known by strong legitimacy, due the indispensable participation of the community in each step.

To constitute a Resex, three stages based on specific legal regulations are pursued; creation, deployment, and management (Fadigas \& Garcia, 2010; Santilli, 2005). Creation arises from a demand by the local community to the government for protection of a given area. It is then established thru an administrative process that allows ample space for popular participation. The deployment phase starts when the Resex is legally constituted, it is characterized by the formation of a deliberative council, and a management plan. Finally, the Resex management occurs jointly between the community involved, public environmental agencies, and universities or other institutions related to the issue.

In the process of creating this Resex, the fishing communities (not considering the dynamics of the estuary as a whole) at first acted separately according to the existing geopolitical division between the states of Paraíba and Pernambuco. Yet, due to certain inconsistencies, the administrative process was shelved until 2002 when IBAMA finally reviewed and unified the demands of all communities involved.

From 2004 to 2007 the process was consolidated with the completion of area studies and analyses to verify the socioeconomic, environmental and biological aspects. Also within this period, public consultations and meetings in all the affected communities took place, legitimizing the creation of an extractive reserve. Consultations were undertaken in a unique context where the community, representatives of business activities, and environmental technicians debated over land use and limits where a single environment meets diverse interests. At this stage, the participation of the fisherwomen, and their leadership was essential to keep the community cohesive and alert concerning the importance of the protected area.

After this broad administrative process, the Marine Extractive Reserve Acaú-Goiana was created by decree on the 26th of September, 2007 (D.O.U., 2007), and is comprised of $6.678,30$ hectares which include the whole estuarine area for the rivers Goiana and Megaó, and the surrounding zones.

\section{CONCLUSION}

In coastal areas with fishing populations, they have become essential to conservation actions. They demonstrate thorough knowledge of the environment, and notice changes in environmental quality even before state environmental agencies. Because of their strong dependence on the environment, they lead the government to adopt measures that enable coastal conservation.

Therefore, we conclude that it is essential to recognize and to work in collaboration with the "unofficial" environmental managers, as the fisherwomen. The empowerment, inclusion, and visibility of the fisherwomen, who have particular knowledge of vital coastal ecosystems such as the estuaries, consolidate equitable interactions between society and nature, bringing positive consequences to coastal environment conservation.

\section{REFERENCES}

Agarwal, B. (1997) - Editorial: Resounding the Alert: Gender, Resources and Community Action. World Development, 25(9):1373-1380. doi: 10.1016/S0305750X(97)00062-4

Aguilar, L.; Briceño, G.; Valenciano, I.; Chacón, E. (1999) Qui cherche trouve: Elaboration de diagnostics participatifs selon une démarche soucieuse d'équité entre les sexes. 84p., $1^{\text {st }}$ ed., UICN, San José, Costa Rica. ISBN: 9968786179. Available from http://www.genderandenvironment.org/ index.php?option $=$ com_docman $\&$ task $=$ doc_download \&gid=1 825\&Itemid=630\&lang=es

Aguilar, L.; Castañeda, I. (2000) - Sobre marinos, marinas, mares y mareas: Perspectivas de género en zonas marinocosteras. 269p., $1^{\text {st }}$ ed., UICN, San José, Costa Rica. ISBN: 9968743402. Available from www.iucn.org/dbtw-wpd/ edocs/2000-042.pdf

Barreira, C.A.R.; Araújo, M.L.R. (2005) - Ciclo reprodutivo de anomalocardia brasiliana (GMELIN, 1791) (MOLLUSCA, BIVALVIA, VENERIDAE) na praia do Canto da Barra, Fortim, Ceará, Brasil. Boletim do Instituto de Pesca (ISSN:1678-2305), 31(1):9-20, São Paulo, SP, Brazil. Available from ftp://ftp.sp.gov.br/ ftppesca/Barreira31_1.pdf

Berkes, F.; Colding, J.; Folke, C. (2000) - Rediscovery of traditional ecological knowledge as adaptive management. EcologicalApplications, 10(5):1251-1262.doi:10.1890/10510761(2000)010[1251:ROTEKA]2.0.CO;2

Campbell, L.M.; Vainio-Mattila, A. (2003) - Participatory development and community-based conservation: Opportunities missed for lessons learned? Human Ecology, 31(3):417-437. doi: 10.1023/A:1025071822388

Cardoso, E. (2003) - Da apropriação da natureza à construção de territórios pesqueiros. GEOUSP Espaço e Tempo (ISSN: 2179-0892), 14:119-125, São Paulo, SP, Brazil. Available from www.geografia.fflch.usp.br/ publicacoes/.../Geousp_14_Cardoso.htm

CPRH (2003) - Diagnóstico socioambiental litoral norte, Pernambuco, 2003. CPRH - Agência Estadual de Meio Ambiente, Recife, PE, Brazil. Available from http://www. cprh.pe.gov.br/central_servicos/centro_documentacao_ informacao_ambiental/central_downloads/39749;3400 1;020709;0;0.asp 
D.O.U. (2000) - Lei no 9.985, de 18 de Julho de 2000 Institui o Sistema Nacional de Unidade de Conservação e dá outras providências. Published in Diário Oficial da União de 19.7.2000, Brasília, DF, Brazil. Available from www.planalto.gov.br/ccivil_03/leis/L9985.htm

D.O.U. (2007) - Decreto de 26 de Setembro de 2007 Cria a Reserva Extrativista Acaú-Goiana, nos Municípios de Pitimbú e Caaporã, no Estado da Paraíba, e Goiana, no Estado de Pernambuco, e dá outras providências. Published in Diário Oficial da Uniáo de 27.9.2007, Brasília, DF, Brazil. Available from http://www. planalto.gov.br/ccivil_03/_Ato2007-2010/2007/Dnn/ Dnn11351.htm

Denzin, N.K.; Lincoln, Y.S. (2003) - Collecting and Interpreting Qualitative Materials. 682p., $2^{\text {nd }}$ ed., Sage Publications, USA. ISBN: 0761926879.

Dias, T.L.P.; Rosa. R.S.; Damasceno, L.C.P. (2007) - Aspectos socioeconômicos, percepção ambiental e perspectivas das mulheres marisqueiras da Reserva de Desenvolvimento Sustentável Ponta do Tubarão (Rio Grande do Norte, Brasil). Gaia Scientia (ISSN: 1981-1268), 1(1):25-35, João Pessoa, PB, Brazil. Available from http://periodicos. ufpb.br/ojs/index.php/gaia/article/view/2225

Di Ciommo, R.C.; Schiavetti, A. (2012) - Women participation in the management of a Marine Protected Area in Brazil. Ocean \& Coastal Management, 62:15-23. doi: 10.1016/j.ocecoaman.2012.02.010

Fadigas, A.B.M; Garcia, L.G. (2010) - Uma análise do processo participativo para a conservação do ambiente na criação da Reserva Extrativista Acaú-Goiana. Sociedade \& Natureza, 22(3):561-576. doi: 10.1590/S198245132010000300012

Griffin, L. (2009) - Scales of knowledge: North Sea fisheries governance, the local fisherman and the European scientist. Environmental Politics, 18(4):557-575. doi: 10.1080/09644010903007419

Hanazaki, N.; Castro, F.; Oliveira, V.G.; Peroni, N. (2007) - Between the sea and the land: The livelihood of estuarine people in southeastern Brazil. Ambiente \& Sociedade, 10(1):121-136. doi: 10.1590/S1414753X2007000100008

Hapke, H.M. (2001) - Petty traders, gender, and development in a south Indian fishery. Economic Geography (ISSN:00130095), 77(3):225-249, Worcester, MA, USA. Available from http://www.jstor.org/stable/3594073

Heyman, W.D.; Granados-Dieseldorff, P. (2012) - The voice of the fishermen of the Dulf of Honduras: Improving regional fisheries management through fisher participation. Fisheries Research, 125-126: 129-148. doi:10.1016/j.fishres.2012.02.016

IBAMA (2002) - Processo no 2001.000442/02-71-2002 Solicitação da Criação da Reserva Extrativista Marinha: RESEX. IBAMA - Instituto Brasileiro do Meio Ambiente e dos Recursos Naturais Renováveis, Brasília, DF, Brazil. Not published.

IBGE (2006) - Censo Agropecuário 2006, Brasil. IBGE - Instituto Brasileiro de Geografia e Estatística, Rio de Janeiro, RJ, Brazil. ISSN: 0103-6157. Available from http://www.ibge.gov.br/home/estatistica/ economia/agropecuaria/censoagro/brasil_2006/Brasil_ censoagro2006.pdf
Levin, J. (1987) - Estatística Aplicada a Ciências Humanas. 392p., $2^{\text {nd }}$ ed., Habra, São Paulo, SP, Brazil. ISBN: 8529402073.

Lopes, V.F.M.; Mattos, U.A.O.; Lianza, S.; Silva, E.R.; Santos, P.R. (2011) - Dinâmicas territoriais e a organização dos pescadores: A experiência da rede solidária da pesca no Brasil. Revista da Gestão Costeira Integrada, 11(2):187196. doi: $10.5894 /$ rgci230

Machado, D. (2007) - Catadoras de caranguejo e saberes tradicionais na conservação de manguezais da Amazônia brasileira. Estudos Feministas, 15(2):485-490. doi: 10.1590/S0104-026X2007000200016

Oliveira, N.M. (1993) - Rainha das águas, donas do mangue: um estudo do trabalho feminino no meio ambiente marinho. Revista Brasileira de Estudos Populacionais (INSS:0102-3098), 10(1):71-88, Campinas, SP, Brazil. Available from http://www.abep. nepo.unicamp.br/docs/rev_inf/vol10_n1e2_1993/ vol10_n1e2_1993_6artigo_71_88.pdf

Rebouças, G.N.M.; Filardi, A.C.L.; Vieira, P.F. (2006) - Gestáo integrada e participativa da pesca artesanal: potencialidades e obstáculos no litoral do estado de Santa Catarina. Ambiente \& Sociedade, 9(2):83-104. doi: 10.1590/S1414-753X2006000200005

Rossman, G.B.; Rallis, S.F. (2003) - Learning in the Field - An Introduction to Qualitative Research, 369p., $2^{\text {nd }}$ ed., Sage Publications, USA. ISBN: 0761926518.

Santilli, J. (2005) - Socioambientalismo e Novos Direitos. 303p., Ed. Peirópolis, Sáo Paulo, SP, Brazil. ISBN: 8575960407.

Silvano, R.A.M.; Valbo-Jørgensen, J. (2008) - Beyond fishermen's tales: Contribution of fishers' local ecological knowledge to fish ecology and fisheries management. Environment, Development and Sustainability, 10(5):657675. doi: 10.1007/s10668-008-9149-0

Simonian, L.T.L. (2006) - Pescadoras de camarão: Gênero, mobilização e sustentabilidade na Ilha Trambioca, Barcarena, Pará. Boletim do Museu Paraense Emílio Goeldi, 1(2): 35-52. doi: 10.1590/S1981-81222006000200004

Soma, K.; Vatn, A. (2009) - Local democracy implications for coastal zone management - A case study in southern Norway. Land Use Policy, 26:755-762. doi: 10.1016/j. landusepol.2008.10.002

Spink, M.J.P. (1995) - Desvendando as teorias implícitas: uma metodologia de análise das representaçôes sociais. In: Jovchelovitch, S.; Guareschi, P. (org.), Textos em Representaçôes Sociais, pp.117-145, $2^{\text {nd }}$ ed., Vozes, Petrópolis, RJ, Brazil. ISBN: 8532612970.

Thomson, K.; Gray, T. (2009) - From community-based to co-management: Improvement or deterioration in fisheries governance in the Cherai Poyil fishery in the Cochin Estuary, Kerala, India? Marine Policy, 33: $537-$ 543. doi: 10.1016/j.marpol.2008.12.012

Zhao, M.; Tyzack, M.; Anderson, R.; Onoakpovike, E. (2012) - Women as visible and invisible workers in fisheries: A case study of Northern England. Marine Policy, 37: 69-76. doi: 10.1016/j.marpol.2012.04.013 